\title{
Analisa Hambatan dan Pitching Moment Equilibrium Pada Kapal Planing Jenis Monohull With Tranverse Step Pada Perairan Calm Water
}

\author{
Pradipta Rahman Hakim, dan IKAP Utama \\ Teknik Perkapalan, Fakultas Teknologi Kelautan, Institut Teknologi Sepuluh Nopember (ITS) \\ e-mail:kutama@na.its.ac.id
}

\begin{abstract}
Abstrak-Penggunaan transverse step pada bagian bawah lambung kapal memiliki beberapa keuntungan apabila digunakan pada kecepatan optimumnya, diantaranya mengurangi momen pitching yang dialami kapal dan megurangi hambatan dalam hal ini adalah friction resistance. Transverse step diaplikasikan pada kapal planing dengan kecepatan tinggi. Untuk membuktikan hal tersebut, dalam studi ini dilakukan penelitian dalam bentuk simulasi Computational Fluid Dynamic (CFD) dengan cara membandingkan dua lambung kapal planing jenis lambung tunggal tanpa dan dengan transverse step pada kondisi air tenang dengan menggunakan froude number 1,5 hingga 2,5. Hasil dari simulasi sudut trim pada kedua jenis kapal menunjukan perbedaan yang signifikan pada tiap variasi kecepatan. Kapal dengan transverse step memiliki sudut trim yang lebih besar dibandingkan dengan kapal tanpa transverse step namun memiliki perbedaan sudut trim yang lebih kecil pada variasi froude number 1,5 hingga 2,5 sebesar $50,62 \%$ yaitu senilai 1,51 derajat. Hambatan kapal pada kedua jenis kapal memiliki perbedaan pada simulasi yang dilakukan. Hasil yang didapatkan yaitu kapal dengan transverse step memiliki nilai hambatan yang lebih kecil pada froude number 1,75 hingga 2,5 yaitu sebesar $14,16 \%$ yaitu senilai $3001,16 \mathrm{~N}$ namun memiliki hambatan yang lebih besar pada froude number 2,5 .
\end{abstract}

Kata Kunci-Kapal Planing, Transverse step, Pitching Moment Equilibrium, Hambatan Kapal, CFD.

\section{PENDAHULUAN}

$\mathrm{T}$ REN desain kapal cepat di dunia saat ini menunjukan bahwa bentuk lambung kapal bagian bawah (wetted surface area) sangat diperhatikan. Hal ini dibuktikan dengan desain lambung yang lebih mementingkan efisiensi dibandingkan dengan estetika. Salah satu desain lambung kapal cepat yang menjadi primadona pada saat ini adalah desain lambung dengan menggunakan transverse step.

Desain lambung kapal cepat dengan menggunakan transverse step sering disalahartikan sebagai desain lambung yang lebih cepat dan lebih efisien jika dibandingkan dengan lambung kapal tanpa transverse step dengan mesin yang sama. Hal ini mungkin tidak salah, namun terlalu berlebihan jika dikatakan bahwa tujuan utama dibuatnya lambung dengan transverse step adalah untuk mengurangi hambatan kapal [1].

Kelebihan dari lambung dengan transverse step memang mengurangi hambatan hingga $8-12 \%$, namun selain itu kelebihan lain adalah mengurangi pitch dan menambah pitch control ketika berjalan di laut [2].

Pada dasarnya, pengaplikasian transverse step seperti pada Gambar 1 pada kapal planing bukan semata karena kelebihannya dalam segi hambatan. Ketika seseorang ingin memindahkan titik berat kapal menjadi lebih kedepan, salah satu alasan pentingnya memindah titik berat kapal lebih kedepan adalah untuk menghindari porpoising ketika ingin menambah kecepatan kapal maka penambahan transverse step diperlukan. Alasannya adalah kapal tanpa transverse step dengan titik berat kapal yang berada jauh didepan transom, contoh berada di midship kapal memiliki performa yang buruk pada kecepatan rendah hingga sedang.

Dengan memperhatikan permasalahan tersebut, studi mengenai penambahan transverse step pada kapal planing dengan kecepatan tinggi menjadi penting mengingat penelitian mengenai topik tersebut masih jarang dilakukan.

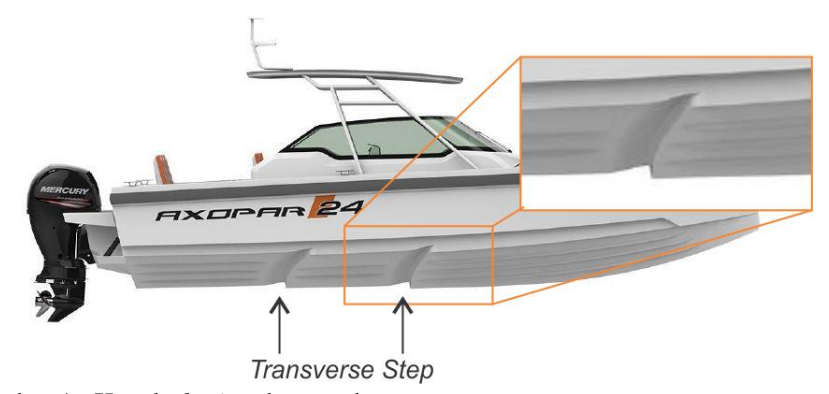

Gambar 1. Kapal planing dengan dua transverse step.

\section{TINJAUAN PUSTAKA}

Salah satu penelitian yang paling terkenal mengenai kapal planing dilakukan oleh Savitsky [3], dimana untuk pertama kalinya memperkenalkan pendekatan matematika untuk memprediksi performa kapal planing seperti friction resistance, pressure resistance, sudut trim dan parameter hidrodinamis lainnya berdasarkan serangkaian eksperimen.

Banyak penelitian yang dilakukan mengenai prediksi performa kapal planing setelah penelitan yang dilakukan Savitsky [3], namun penelitian mengenai performa kapal planing dengan transverse step masih sedikit.

Setelah melakukan pencarian terhadap referensi penelitian mengenai kapal dengan transverse step yang telah dilakukan, didapatkan beberapa penelitian mengenai lambung kapal 
dengan transverse step. Penelitan yang pertama adalah penelitian yang dilakukan oleh Svahn [1] mengenai lambung dengan transverse step dengan menggunakan permodelan matematika mengenai prediksi gerak lambung dilihat dari pitching moment yang dialami kapal. penelitian yang dilakukan Svahn [1] memiliki kemiripan dengan penelitian kedua yaitu penelitian yang dilakukan oleh Matveev [4] yang sama-sama melakukan penelitian dengan menggunakan permodelan matematika. Perbedaannya adalah tujuan penelitian yang dilakukan Matveev [4] yaitu memprediksi hambatan pada kapal dengan transverse step dengan menggunakan two dimensional mathematical method.

Referensi penelitian ketiga adalah penelitian yang dilakukan oleh Garland [5] mengenai investigasi kapal dengan transverse step dengan metode uji tarik untuk mengetahui hambatan kapal dengan fungsi objektif berupa tinggi step dihitung dari baseline. Referensi penelitan yang keempat adalah penelitian yang dilakukan oleh Gassemi [6] dimana penelitian ini meneliti hambatan kapal Stepped Hull dengan variasi LCG, L/B, dan kecepatan kapal pada calm water. Penilitian ini memiliki kemiripan dengan yang dilakukan oleh Svahn [1] dan Gassemi [6] dimana sama-sama meneliti performa pada transverse step hull. Perbedaannya terletak pada output dimana penelitian yang dilakukan Svahn [1] hanya meneliti lambung dengan step tanpa membandingkan dengan lambung tanpa step dan hanya menggunakan permodelan matematika saja. sedangkan pada penelitian Gassemi [6], penelitian dilakukan, output yang dituju hanya hambatan saja tanpa menghitung pitching moment equilibrium.

\section{DASAR TEORI}

\section{A. Teori Kapal Planing}

Kapal planing merupakan salah satu jenis kapal yang mempunyai tingkat efisiensi yang baik sebagai kapal cepat. Kapal ini bergantung pada kecepatan yang mengangkat sebagian lambungnya keluar dari air (hydrodynamic support). Dengan kecilnya badan kapal yang bersentuhan dengan air maka kecil juga jumlah tahanan air yang ditanggung. Bentuk badan kapal dirancang mengikuti hukum hydrodynamic [3], setiap benda yang bergerak yang dapat menciptakan aliran nonsimetris menimbulkan gaya angkat yang tegak lurus dengan arah gerak. Seperti sayap pesawat terbang yang bergerak di udara akan memberi gaya angkat.

Pengukuran yang umum digunakan untuk mengetahui karakteristik hambatan dan bentuk gelombang pada kapal planing adalah dimensionless froude number ( $\mathrm{Fr}$ ), yang berhubungan dengan gaya inersia dan gaya eksternal [3]. Rumus untuk mendapatkan nilai Froude number adalah sebagai berikut.

$$
F r=\frac{V}{\sqrt{g \cdot L w l}}
$$

\section{B. Hambatan Pada Kapal Planing}

Kapal planing memiliki dua komponen gaya yang bekerja yaitu hydrostatic force dan hydrodynamic force sehingga metode untuk memprediksi hambatan kapal planing berbeda dari metode untuk memprediksi hambatan kapal displasmen. Hambatan hidrodinamis total pada kapal planing terdiri dari hambatan akibat tekanan normal pada dasar kapal dan hambatan viskos tangensial pada dasar kapal di bagian pressure area maupun pada spray area [7]. Dalam jurnal tersebut dikatakan bahwa apabila pada bagian samping kapal termasuk dalam permukaan area basah (WSA) maka komponen hambatan viskos tambahan harus dimasukan, namun pada analisa dalam jurnal tersebut, diibaratkan bahwa bagian samping kapal tidak terkena air sama sekali.

Maka dapat dituliskan hambatan kapal pada fluida adalah sebagai berikut.

$$
\mathrm{D}=\Delta \tan \tau+\frac{\mathrm{C}_{\mathrm{f}} \rho \mathrm{V}_{1}^{2}\left(\lambda \mathrm{b}^{2}\right)}{2 \cos \beta \cos \tau}
$$

\section{Gaya Angkat Pada Kapal Planing}

Pada kecepatan yang sangat rendah atau pada saat keadaan diam, gaya angkat yang mendominasi adalah gaya hidrostatis, namun seiring bertambahnya kecepatan efek gaya angkat hidrodinamis mulai timbul. Pada kecepatan yang sangat tinggi, gaya hidrodinamis menjadi gaya yang dominan dalam memberikan gaya angkat pada kapal planing. Rumus empiris untuk mendapatkan nilai gaya angkat hidrodinamis kapal dengan sudut deadrise nol adalah sebagai berikut.

$$
C_{L}=\tau^{1.1}\left[0.0120 \lambda^{1 / 2}+\frac{0.0055 \lambda^{5 / 2}}{C_{V}^{2}}\right]
$$

Untuk sudut trim dan rasio panjang-lebar luasan basah yang telah diberikan, efek yang terjadi dari penambahan sudut deadrise adalah pengurangan gaya angkat pada kapal planing. Pengurangan gaya angkat ini disebabkan oleh pengurangan luasan basah pada stagnation pressure di leading edge. Sehingga rumus untuk kapal dengan sudut deadrise tidak sama dengan nol adalah sebagai berikut.

$$
C_{L_{\beta}}=C_{L_{0}}-0.0065 \beta C_{L_{0}}^{0.60}
$$

\section{Pitching Moment Equilibrium}

Pada jurnal Savitsky [3] diberikan metode untuk memprediksi performa kapal planing. Perhitungan tersebut melibatkan penentuan sudut trim kapal dan hambatan kapal ketika berjalan dimana hal tersebut akan menghasilkan kondisi kesetimbangan pada badan kapal pada kecepatan, beban, dan titik berat yang diberikan. Gambaran mengenai gaya dan momen yang bekerja pada kapal digambarkan pada Gambar 2, dengan begitu kesetimbangan gaya dan momen diberikan dengan rumus sebagai berikut. 


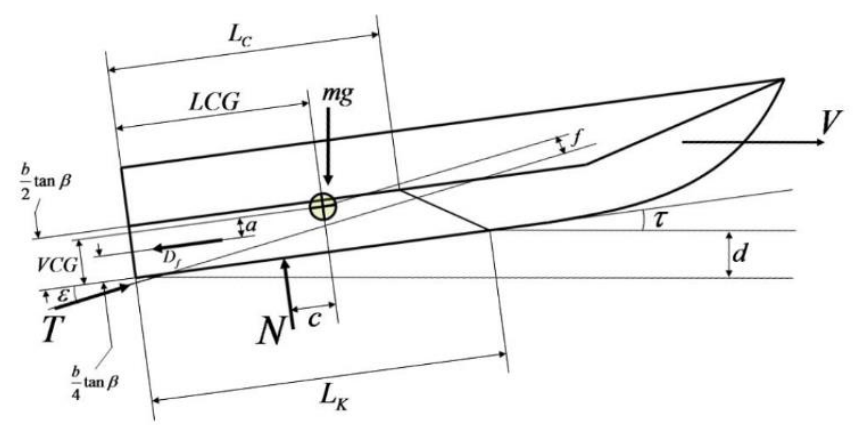

Gambar 2. Gaya yang bekerja pada kapal planing tanpa transverse step

Untuk kesetimbangan gaya vertikal :

$$
\uparrow: N \cos \tau+T \sin (\tau+\varepsilon)-m g-D_{f} \sin \tau=0
$$

Untuk kesetimbangan gaya horizontal :

$$
\rightarrow: T \cos (\tau+\varepsilon)-N \sin \tau-D_{f} \cos \tau=0
$$

Untuk kesetimbangan pitching moment :

$$
M=N \cdot c+D_{f} \cdot a-T \cdot f=0
$$

\section{METODOLOGI}

\section{A. Studi Literatur}

Tahap pengerjaan yang pertama dilakukan adalah mendapatkan data-data pendukung dalam penelitian ini. Datadata pendukung tersebut adalah berupa penelitian yang telah dilakukan sebelumnya mengenai topik yang sama yaitu kapal dengan transverse step. Tahap ini berguna untuk mempersingkat waktu dalam mendapatkan data kapal yang optimal sehingga hasil dalam penelitian ini dapat membuktikan hipotesis yang telah dibuat sebelumnya. Data pendukung tersebut berupa ukuran utama kapal, kecepatan kapal, tinggi step, letak step, letak longitudinal center of gravity, dan data pendukung lainnya. Hasil dari studi literature dapat dilihat pada Tabel 1.

\begin{tabular}{|c|c|c|c|c|}
\hline \multirow{2}{*}{$\begin{array}{c}\text { No } \\
\text {. }\end{array}$} & \multirow[t]{2}{*}{ Komponen } & \multicolumn{2}{|c|}{ Nilai } & \multirow[t]{2}{*}{ Unit } \\
\hline & & $\begin{array}{c}\text { Tanpa } \\
\text { transverse } \\
\text { step }\end{array}$ & $\begin{array}{c}\text { Dengan } \\
\text { transverse } \\
\text { step }\end{array}$ & \\
\hline 1 & Displacement & 1452.57 & 1457.4 & $\mathrm{~kg}$ \\
\hline 2 & Volume & 1417136 & 1421854.32 & $\mathrm{~cm} 3$ \\
\hline 3 & Draft & 33.3 & 34.8 & $\mathrm{~cm}$ \\
\hline 4 & Lwl & 6.33 & 6.2012 & $\mathrm{~m}$ \\
\hline 5 & Beam Waterline & 1779.8 & 1789.8 & $\mathrm{~cm}$ \\
\hline 6 & LoA & 7300 & 7300 & $\mathrm{~cm}$ \\
\hline 7 & Letak Step & 2.55 & - & $\mathrm{m}$ dari $\mathrm{AP}$ \\
\hline 8 & Tinggi Step & 0.08 & - & $\mathrm{m}$ \\
\hline 9 & $\mathrm{CB}$ & 0.378 & 0.366 & - \\
\hline 10 & LCB & 273.58 & 265.34 & - \\
\hline 11 & $\mathrm{Cp}$ & 0.729 & 0.708 & - \\
\hline 12 & $\mathrm{Cm}$ & 0.584 & 0.611 & - \\
\hline 13 & Cwp & 0.739 & 0.729 & - \\
\hline 14 & $\mathrm{~L} / \mathrm{B}$ & 4.101584448 & 4.078668008 & - \\
\hline
\end{tabular}

Tabel 1.

Ukuran Utama Kapal Dengan Transverse Step Dan Tanpa Transverse Step

\section{B. Permodelan Kapal}

Pemodelan lambung kapal yang akan digunakan sebagai input pada perangkat lunak Numeca dengan menggunakan bantuan software Maxsurf Modeler seperti pada Gambar 3. Maxsurf membuat model lambung kapal yang terdiri dari beberapa surface dengan fitur 3D NURB (Non-Uniform Rational B-Spline). Database yang akan digunakan pada tahap ini adalah linesplan kapal Clarion 23 Runabout dan disesuakan dengan data kapal seperti ukuran utama dan displacement.

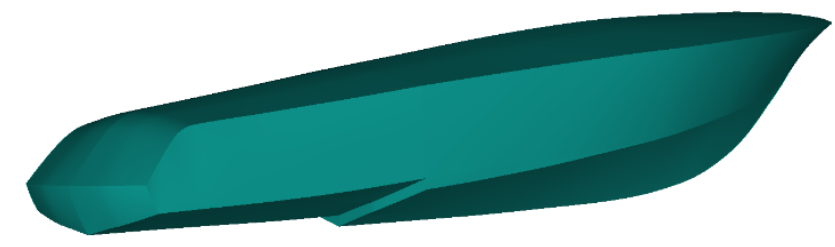

Gambar 3. Model 3D kapal dengan transverse step

\section{Simulasi $C F D$}

Software Numeca FineMarine merupakan salah satu dari sekian banyak perangkat lunak untuk simulasi CFD dalam hal ini bertujuan untuk mendapatkan nilai hambatan dan pitching moment kapal. Salah satu kelebihan perangkat lunak ini adalah kemudahan yang diberikan mengingat perangkat lunak tersebut memang dikhususkan untuk mensimulasikan kapal.

Metode yang digunakan dalam software ini adalah finite volume method yang merupakan metode numerik dimana dalam metode ini dilakukan diskretisasi, dimana diskretisasi adalah memecah domain atau daerah perhitungan menjadi beberapa daerah kecil yang disebut dengan mesh, grid, atau cell [8]. Metode CFD ini dilakukan dengan menggunakan lima variasi kecepatan seperti yang dapat dilihat pada tabel 2 . Froude number yang digunakan dalam penelitian ini menggunakan panjang luasan basah dan volume yang konstan yang diukur pada saat kapal dalam keadaan diam.

\begin{tabular}{|c|c|c|c|c|}
\hline \multirow{2}{*}{ Fr V } & \multirow{2}{*}{ Fr Lwl } & \multicolumn{2}{|c|}{ Kecepatan } & \multirow{2}{*}{ Unit } \\
\hline & & Tanpa Step & $\begin{array}{c}\text { Dengan } \\
\text { Step }\end{array}$ & \\
\hline 1,12 & 1,5 & 11,82 & 11,70 & $\mathrm{~m} / \mathrm{s}$ \\
\hline 1,30 & 1,75 & 13,79 & 13,65 & $\mathrm{~m} / \mathrm{s}$ \\
\hline 1,49 & 2 & 15,77 & 15,60 & $\mathrm{~m} / \mathrm{s}$ \\
\hline 1,68 & 2,25 & 17,74 & 17,55 & $\mathrm{~m} / \mathrm{s}$ \\
\hline 1,86 & 2,5 & 19,71 & 19,50 & $\mathrm{~m} / \mathrm{s}$ \\
\hline
\end{tabular}

Tabel 2.

Variasi kapal dengan transverse step dan tanpa transverse step

Langkah-langkah yang perlu dilakukan dalam simulasi CFD adalah pembuatan geometri kapal, pembuatan boundary condition, mesh generation, dan solver. Boundary condition dibuat untuk mendefinisikan batasan di dalam simulasi seperti yang dapat dilihat pada Gambar 5. Proses mesh generation dilakukan untuk membuat domain atau bagian kecil hasil diskretisasi atau pemecahan domain dalam finite volume method. Hasil meshing dapat dilihat pada Gambar 4. 


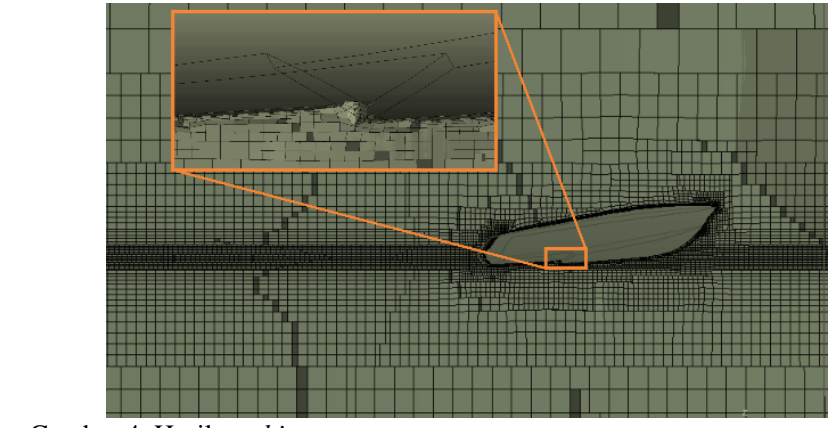

Gambar 4. Hasil meshing

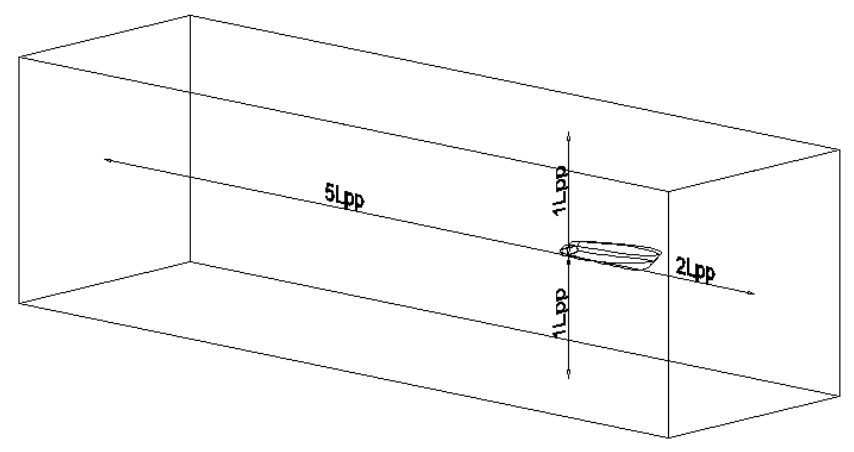

Gambar 5. Boundary Condition Definition

\section{Perhitungan Pitching Moment Equilibrium}

Untuk mendapatkan nilai pitching moment equilibrium, nilai momen yang didapat dicari hingga mendapatkan dua nilai yang bernilai positif dan negatif. Kedua nilai tersebut kemudian diinterpolasi linear, sehingga didapatkan nilai sudut trim yang telah diinterpolasi. Momen positif, momen negatif dan momen yang telah diinterpolasi tersebut kemudian dicari nilai kesalahannya dengan meggunakan metode standar deviasi.

\section{E. Analisa Hambatan dan Sudut Trim Kapal}

Setelah didapatkan performa kapal, dalam hal ini adalah sudut trim yang telah memenuhi pitching moment equilibrium, anaisa hambatan dan gaya angkat dapat dilakukan. Dalam proses analisa tersebut, nilai hambatan dan nilai gaya angkat kapal dikoreksi dengan metode interpolasi linear. Setelah didapatkan tiga nilai hambatan dan gaya angkat pada tiga sudut trim yang nilainya mendekati nilai nol, ketiga nilai tersebut dicari nilai kesalahannya dengan menggunakan metode standar deviasi.

\section{F. Diagram Alir}

Secara umum, metode yang telah dijelaskan diatas dapat dibuat menjadi sebuah diagram alir yaitu diagram yang menunjukan proses yang dilakukan dalam penelitian ini dari langkah pertama yaitu perumusan masalah hingga kesimpulan. Diagram alir dalam penelitian ini ditunjukan pada Gambar 6.

\section{ANALISA HASIL DAN PEMBAHASAN}

\section{A. Grid of Independence}

Sebelum penelitian dilakukan, diperlukan perhitungan nilai jumlah cell yang akan dipakai agar hasil penelitian yang dilakukan mendapatkan hasil yang akurat. Nilai jumlah cell

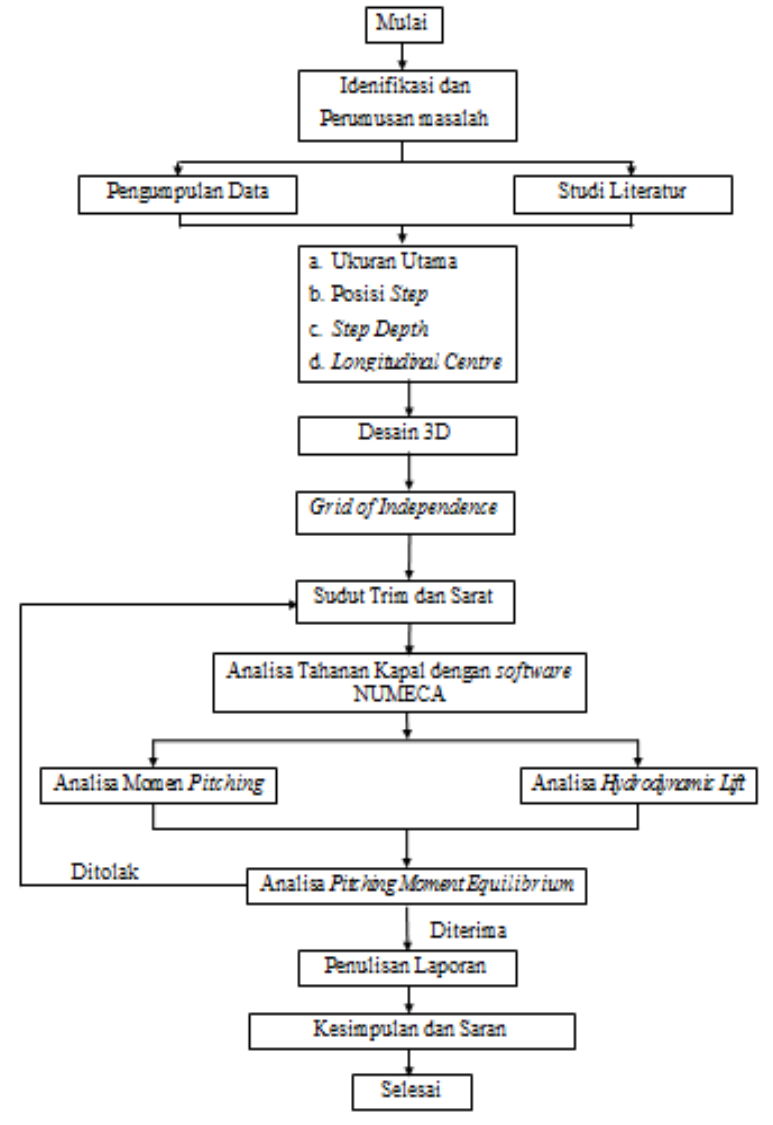

Gambar 6. Diagram Alir

terkecil adalah 0,15 juta elemen sedangkan jumlah cell terbanyak adalah 2,4 juta elemen. Percobaan yang dilakukan untuk mendapatkan nilai grid of independence dilakukan dengan menggunakan lima nilai jumlah cell atau elemen. Hasil perbandingan variasi jumlah elemen dibandingkan dengan hambatan, gaya angkat dan momen kapal ditunjukan pada Tabel 3.

Tabel 3.

Nilai hambatan, gaya angkat dan momen pada variasi jumlah elemen

\begin{tabular}{ccccc}
\hline \hline No & $\begin{array}{c}\text { jumlah } \\
\text { elemen }\end{array}$ & $\begin{array}{c}\text { Drag } \\
{[\mathrm{N}]}\end{array}$ & $\begin{array}{c}\text { lift } \\
{[\mathrm{N}]}\end{array}$ & $\begin{array}{c}\text { moment } \\
{[\mathrm{Nm}]}\end{array}$ \\
\hline 1 & 150000 & 5301 & 28914,54 & $-7381,75$ \\
2 & 300000 & 4831 & 27948,26 & $-7240,08$ \\
3 & 600000 & 4361 & 26981,98 & $-7098,41$ \\
4 & 1200000 & 3268 & 24491,73 & $-6434,38$ \\
5 & 2400000 & 3279 & 24582,91 & $-6450,44$ \\
\hline \hline
\end{tabular}

Pada tabel tersebut, terlihat pebedaan antara hambatan, gaya angkat dan momen kapal pada tiap-tiap variasi jumlah elemen. Perbedaan tersebut semakin mengecil pada elemen dengan jumlah yang besar dimana dapat dilihat pada Gambar 7.

\section{B. Sudut Trim Kapal}

Sudut trim yang dialami kapal pada lima variasi kapal didapatkan dari hasil koreksi yang dijelaskan pada bab metodologi sebelumnya. Dengan menggunakan cara yang 
sama, dilakukan koreksi terhadap sudut trim yang dialami kapal pada tiap-tiap variasi kecepatan. Sehingga didapatkan hasil yang ditunjukan pada Gambar 8.

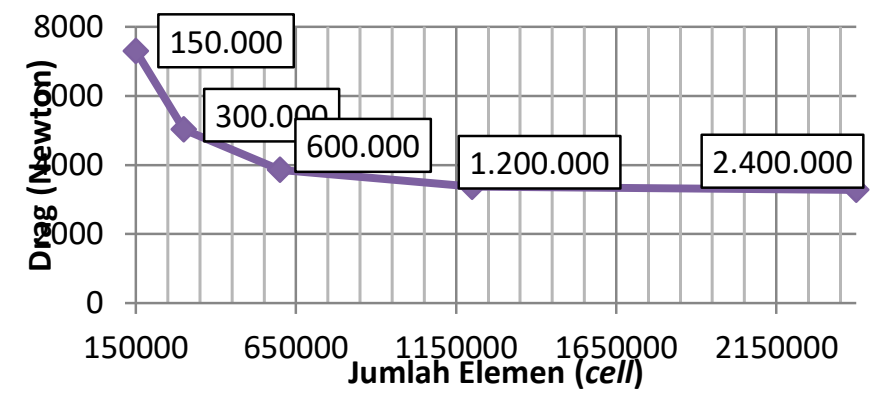

Gambar 7. Grafik perbedaan nilai hambatan kapal tiap variasi jumlah cell.

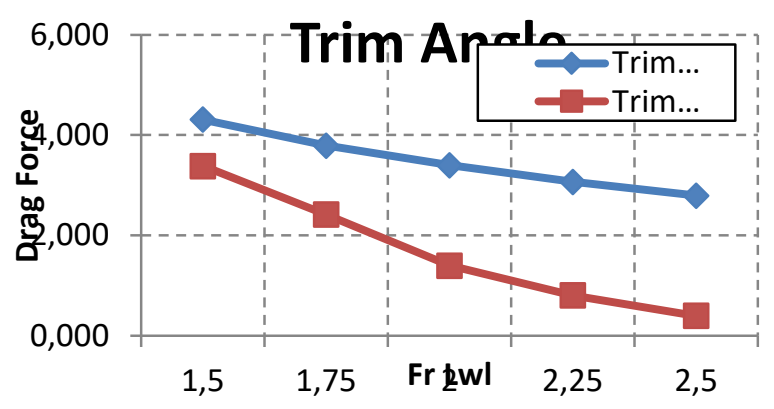

Gambar 8. Grafik perbedaan sudut trim pada tiap Fr Lwl.

Pada gambar tersebut terlihat kapal dengan transverse step dan tanpa transverse step memiliki sudut trim yang berbeda pada tiap-tiap kecepatan. Kapal dengan transverse step cenderung memiliki sudut yang lebih besar dibandingkan kapal tanpa transverse step.

\section{Hambatan Kapal}

Setelah menganalisa grafik sudut trim, selanjutnya adalah menganalisa hambatan kedua variasi kapal. Seperti yang ditunjukan pada Gambar 9, kapal dengan transverse step memiliki hambatan yang besar pada kecepatan awal yaitu pada $1,5 \leq \mathrm{Fr} \leq 1,75$ dibandingkan dengan kapal tanpa transverse step. Namun pada penambahan kecepatan berikutnya, kapal dengan transverse step memiliki hambatan yang lebih kecil dibandingkan dengan kapal tanpa transverse step. Dengan melihat pada Gambar 9 maka dapat disimpulkan bahwa kapal dengan transverse step memiliki kecepatan optimal yaitu pada kecepatan tinggi.

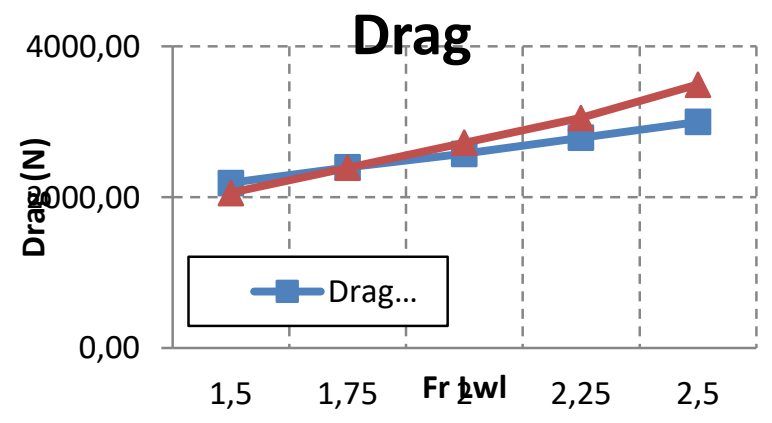

Gambar 9. Grafik perbedaan hambatan pada tiap Fr Lwl.

\section{ANALISA CFD}

Gambar 10 merupakan contoh hasil simulasi CFD kapal tanpa transverse step pada kecepatan $\mathrm{Fn}=2,5$ dengan menggunakan software Numeca. Pada bagian ini akan dibahas mengenai hasil yang didapat dari simulasi yang telah dilakukan pada dua varisai kapal dengan lima variasi kecepatan sehingga didapatkan karakteristik hidrodinamis dari kapal dengan transverse step apabila dibandingkan dengan kapal tanpa transverse step. Karakteristik hidrodinamis yang akan dibahas mengenai simulasi yang telah dilakukan adalah bentuk gelombang, static pressure, dan hydrodynamic pressure.

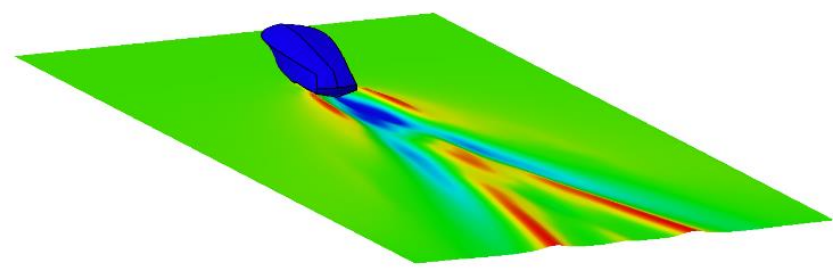

Gambar 10. CFD Analysis dengan menggunakan software Numeca

\section{A. Wave Pattern}

Wave pattern adalah bentuk gelombang dari fluida yang dilewati benda padat yang terbentuk pada bagian samping dan belakang benda tersebut. Wave pattern yang dihasilkan kedua variasi kapal ditunjukan pada Gambar 11. Gambar tersebut menunjukan perbedaan bentuk golombang pada kapal dengan transverse step dan kapal tanpa transverse step pada $\mathrm{Fr}=1,5$ dan $\mathrm{Fr}=2,5$.

Kapal dengan transverse step seperti yang ditunjukan pada Gambar 11.a menunjukan bahwa bentuk gelombang pada bagian samping kapal lebih tinggi pada kecepatan rendah namun lebih rendah pada kecepatan tinggi. Hal tersebut berkebalikan dengan kapal tanpa transverse step dimana bentuk gelombang lebih rendah pada kecepatan rendah namun lebih tinggi pada kecepatan tinggi.

\section{B. Static Pressure}

Pada Gambar 11. Ditunjukan tekanan normal yang dialami lambung kapal pada bagian dasar kapal. Perbedaan gradasi

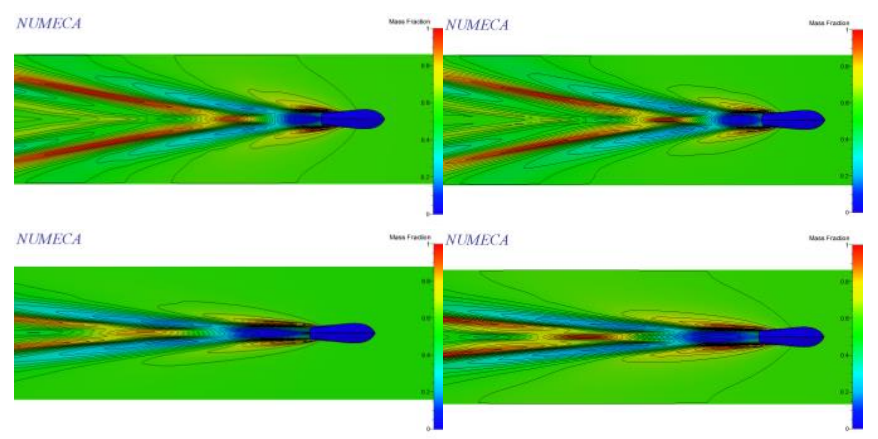

Gambar 11. Wave Pattern pada kapal dengan transverse step (kiri) dan tanpa transverse step (kanan) pada kecepatan $\mathrm{Fr}=1,5$ (atas) dan $\mathrm{Fr}=2,5$ (bawah).

warna menunjukan perbedaan tekanan normal yang dialami tiap-tiap bagian dasar kapal. Warna merah menunjukan bagian 
kapal mengalami tekan yang terbesar sedangkan warna biru menunjukan tekanan yang paling kecil.

\section{Hydrodynamic Pressure}

Pada gambar 13 ditunjukan perbedaan tekanan pada dasar kapal tanpa step pada kecepatan $\mathrm{Fr}=1,5$ dan pada kecepatan $\mathrm{Fr}=2,5$. Terlihat tekanan pada bagian step memiliki tekanan paling kecil dimana ditunjukan pada warna biru sedangkan bagian di belakang step memiliki tekanan yang paling besar ditunjukan dengan bagian warna merah dan kuning. Pada perbedaan kecepatan tersebut, terlihat bahwa tekanan pada bagian dibelakang step pada kecepatan yang lebih tinggi memiliki tekanan yang lebih besar

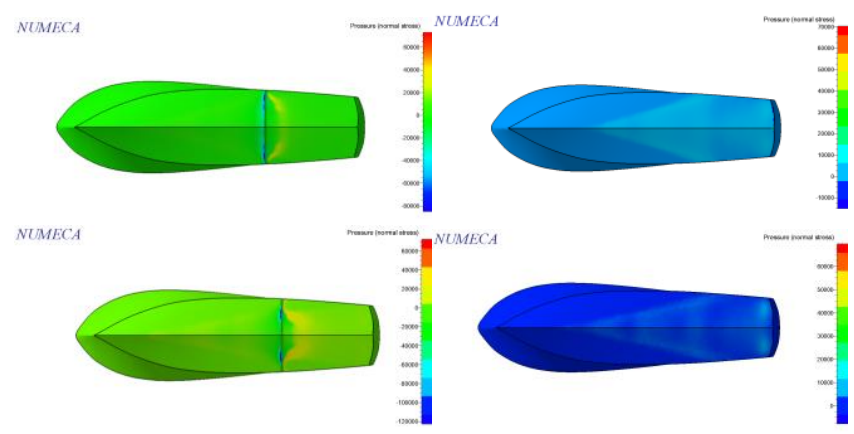

Gambar 12. Static pressure pada kapal dengan transverse step (kiri) dan tanpa transverse step (kanan) pada kecepatan $\mathrm{Fr}=1,5$ (atas) dan $\mathrm{Fr}=2,5$ (bawah).

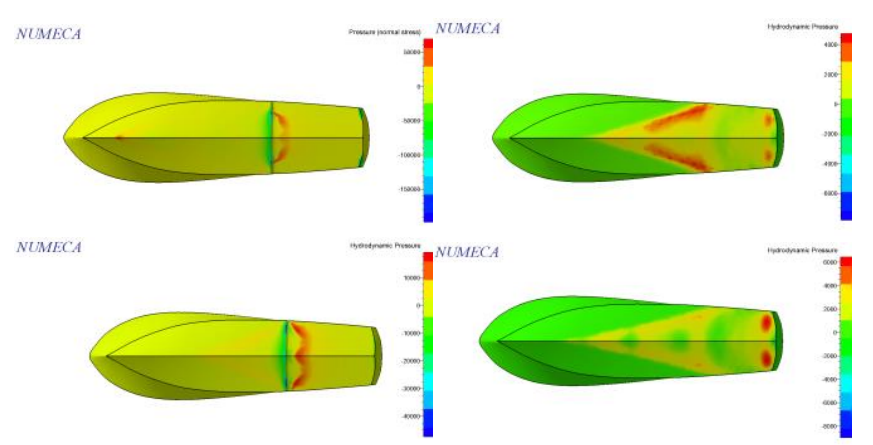

Gambar. 13. Hydrodynamic Pressure pada kapal dengan transverse step (kiri) dan tanpa transverse step (kanan) pada kecepatan $\mathrm{Fr}=1,5$ (atas) dan $\mathrm{Fr}=2,5$ (bawah).

\section{KESIMPULAN}

Simulasi CFD dapat memberikan data yang sulit didapatkan dengan uji eksperimental seperti aliran fluida disekitar lambung kapal dan detail gaya yang bekerja pada tiap bagian lambung kapal. Perangkat lunak Numeca FineMarine berhasil memberikan hasil yang lengkap disertai detail yang memuaskan pada permasalahan dalam penelitian ini.

Simulasi CFD yang dilakukan pada penelitian ini menggunakan data kapal dari penelitian yang telah ada sebelumnya. Data kapal tersebut meliputi tinggi step, letak step, dan letak LCG. Tinggi step yang digunakan adalah 4\% lebar kapal yaitu senilai 0,08m; letak step 30\% dari panjang LoA yaitu 2,2m diukur dari transom kapal dan letak LCG adalah $35 \%$ panjang LoA yaitu 2,55m diukur dari transom kapal. Hasil yang didapatkan dengan menggunakan konfigurasi tersebut adalah kapal dengan transverse step memiliki perbedaan sudut pada $1.5 \leq \mathrm{Fr} \leq 2,5$ lebih kecil $50,62 \%$ yaitu sebesar 1,5 derajat. Dari segi hambatan, kapal dengan transverse step memiliki hambatan kapal yang lebih kecil dibanding kapal tanpa transverse step pada $\mathrm{Fr} \geq 1,75$ namun memiliki hambatan yang lebih besar pada $\mathrm{Fr} \leq 1,75$. Hambatan kapal pada $\mathrm{Fr}=2$ lebih kecil 5,33\% dengan nilai 2578,22N. Pada $\mathrm{Fr}=2,25$ lebih kecil 8,56\% dengan nilai $2791,03 \mathrm{~N}$; dan pada $\mathrm{Fr}=2,5$ lebih kecil 14,16\% dengan nilai 3001,16N.

Dengan melihat hasil yang didapatkan pada simulasi, dapat disimpulakan bahwa kapal dengan transverse step memiliki pitch control yang lebih baik dan nilai hambatan yang lebih kecil apabila diaplikasikan pada kapal dengan Froude number tinggi $(\mathrm{Fr} \geq 1,75)$ dibandingkan kapal tanpa transverse step.

\section{UCAPAN TERIMA KASIH}

Penulis menyampaikan penghargaan dan ucapan terima kasih yang sebesar-besarnya kepada kepala Laboratorium Hidrodinamika Kapal dan Laboratorium Desain Kapal Departmen Teknik Perkapalan, FTK-ITS dan segenap karyawan yang telah memfasilitasi dan mendukung proses pelaksanaan analisa CFD, sehingga dapat terlaksana dengan baik.

\section{DAFTAR PUSTAKA}

[1] D. Svahn, "Performance Prediction of Hulls with Transverse step," Royal Institute of Technology, 2009.

[2] L. Campbell, "Notes on Step Hull," 2012.

[3] D. Savitsky, "Hydrodynamic Design of Planing Hulls," 1964.

[4] I. K. Matveev, "Two-Dimensional Modelling of Stepped Planing Hulls with Open and Pressurized Air Cavities," Inter J Nav Arch. Oc Engng, vol. 4, p. $162,2012$.

[5] W. R. Garland, "Stepped Planing Hull Investigation," United States Naval Academy, 2010.

[6] S. T. Golah, "Toward Numerical Modeling of the Stepped and Non Stepped," Brazilian Soc. Mech. Sci. Eng., 2014.

[7] et al. Gassemi, H., "A Hydrodynamic Methodology and CFD Analysis for Performance Prediction of Stepped Planing Hull," Polish Marit. Res., vol. 22, pp. 23-31, 2015.

[8] T. D. Frisk. D, "Prediction of High-Speed Planing Hull Resistance and Running Attitude," Chalmers University Of Technology, 2015. 